\title{
Immunostaining of spores and plasmodia of disparate myxozoan genera with comments on the properties of the sporular mucus envelope
}

\author{
D. J. MORRIS ${ }^{1 *}$, K. MOLNÁR ${ }^{2}$, M. LONGSHAW ${ }^{3}$ and A. ADAMS ${ }^{1}$ \\ ${ }^{1}$ Institute of Aquaculture, University of Stirling, Stirling FK9 4LA, UK \\ ${ }^{2}$ Veterinary Medical Research Institute, Hungarian Academy of Sciences, P.O. Box 18, H-1581 Budapest, Hungary \\ ${ }^{3}$ Centre for Environment, Fisheries and Aquaculture Science (CEFAS), Weymouth Laboratory, Barrack Road, The Nothe, \\ Weymouth, Dorset DT4 8UB, UK
}

(Received 10 October 2005; revised 25 November 2005; accepted 26 November 2005; first published online 3 February 2006)

S UMMARY

Species of the phylum Myxozoa are common parasites of fish and can cause severe losses in cultured species. Although a number of myxozoan life-cycles have now been elucidated, little is known about the biology of these organisms in the fish host. Monoclonal antibody B4 raised to the myxozoan Tetracapsuloides bryosalmonae has been previously noted to react with a number of species infecting fish kidney. We present the results of a survey of 55 myxosporean species that determined that this antibody detects an antigen on the spore surface of 33 of these species in the genera Myxobolus, Sphaerospora and Thelohanellus. However, there appears to be no clear relationship between those spores that contain the MAb B4 reactive antigen and the host or organ in which they are detected. The antigen appears to be synthesized in the plasmodial cytoplasm and is intimately associated with the surface of the spore capsules and, where present, the mucus envelope. The nature of this envelope is further discussed in relation to its formation and distinctive properties.

Key words: Myxozoa, Microsporidia, immunohistochemistry, mucus envelope.

\section{INTRODUCTION}

Members of the phylum Myxozoa are primarily parasites of fish, annelids and bryozoa (Kent et al. 2001). The phylum is composed of 2 orders, the Myxosporea and the Malacosporea. Several species can result in disfiguring diseases or significant reductions in the fitness of the host. With the worldwide intensification of aquacultural activities the economic importance of these parasites is increasing. Relatively little is known about myxozoan biology within the fish host although an increasing number of their life-cycles are becoming elucidated.

Monoclonal antibody B4 (mAb B4) was initially developed to the malacosporean Tetracapsuloides bryosalmonae, the parasite that causes proliferative kidney disease (PKD) in salmonid fish (Morris, Adams and Richards, 1997). Immunostaining of mAb B4 against $T$. bryosalmonae demonstrated that it recognized an antigen associated with the renal intra-tubular sporogonic stages of the parasite and developing secondary cells within the histozoic presporogonic (=extrasporogonic) parasites (Marin de

* Corresponding author: Institute of Aquaculture, University of Stirling, Stirling FK9 4LA, UK. Tel: +44 1786 467912. Fax: +44 1786 472133. E-mail. Djm4 (a)stir.ac.uk
Mateo et al. 1996). Further characterization using periodate treatment and immunogold localization demonstrated that the antigen to which $\mathrm{B} 4$ binds (herein referred to as the $\mathrm{B} 4$ antigen) was a protein secreted from these stages (Morris et al. 1997). Initial experiments, examining the specificity of $\mathrm{mAb} \mathrm{B} 4$, were limited to those myxozoan species that infect the renal tissues of fish (Morris et al. 2000; Marin de Mateo et al. 1996). Recently, the antibody has also been identified as cross-reacting with head tissues of rainbow trout Oncorhynchus mykiss infected with Myxobolus cerebralis, the causative agent of 'whirling disease' (Morris, El-Matbouli and Adams, 2004). While expression of the antigen was only present during the intra-piscine sporogony of $M$. cerebralis, the precise parasite developmental stage that produced it could not be identified. The combined results of these specificity studies are listed in Table 1 and demonstrate that the antibody recognizes a range of freshwater myxozoan species. Any relationship between these species, however, is unclear and does not correlate with the known phylogeny of the phylum.

The purpose of this study was to determine whether there is a relationship between those myxozoan species that immunostain using the antibody. The study also examined the localization of the antigen to further understand its expression and the stage of parasite development it is associated with. 
Table 1. Myxozoan species examined to date for their reaction to mAb B4

(All tissues examined were kidney tissues except for Myxobolus cerebralis (head cartilage) and Ceratomyxa shasta (intestine).)

\begin{tabular}{|c|c|c|c|}
\hline Species & Host & Reaction & Reference \\
\hline Ceratomyxa shasta & Oncorhynchus mykiss & - & Marin de Mateo et al. 1996 \\
\hline Chloromyxum sp. & Leuciscus leuciscus & - & Morris et al. 2000 \\
\hline Chloromyxum sp. & Salmo trutta & - & Morris et al. 2000 \\
\hline Hoferellus sp. & Leuciscus leuciscus & - & Morris et al. 2000 \\
\hline Myxidium lieberkuehni & Esox lucius & - & Morris et al. 2000 \\
\hline Myxidium sp. & Anguilla anguilla & - & Morris et al. 2000 \\
\hline Myxobolus cerebralis & Oncorhynchus mykiss & + & Morris et al. 2004 \\
\hline Myxobolus muelleri & Leuciscus leuciscus & - & Morris et al. 2000 \\
\hline Myxobolus sp. & Cottus gobio & - & Morris et al. 2000 \\
\hline Myxobolus sp. & Leuciscus leuciscus & - & Morris et al. 2000 \\
\hline Myxobolus sp. & Rutilus rutilus & - & Morris et al. 2000 \\
\hline Myxobolus sp. & Labeo rohita & + & Petchsupa, 2002 \\
\hline Sphaerospora sp. & Phoxinus phoxinus & - & Morris et al. 2000 \\
\hline Sphaerospora elegans & Pungitius pungitius & - & Morris et al. 2000 \\
\hline Sphaerospora oncorhynchi & Oncorhynchus nerka & + & Marin de Mateo et al. 1996 \\
\hline Sphaerospora renicola & Cyprinus carpio & + & Marin de Mateo et al. 1996 \\
\hline Sphaerospora sp. & Salmo salar & + & Marin de Mateo et al. 1996 \\
\hline Sphaerospora sp. & Coregonus lavaretus & - & Morris et al. 2000 \\
\hline Sphaerospora sp. & Leuciscus leuciscus & - & Morris et al. 2000 \\
\hline Sphaerospora sp. & Rutilus rutilus & - & Morris et al. 2000 \\
\hline Sphaerospora truttae & Salmo trutta & + & Marin de Mateo et al. 1996 \\
\hline \multirow[t]{4}{*}{ Tetracapsuloides bryosalmonae } & Oncorhynchus mykiss & + & Marin de Mateo et al. 1996 \\
\hline & Salmo trutta & + & Morris et al. 2000 \\
\hline & Salmo salar & + & Morris et al. 2000 \\
\hline & Thymallus thymallus & + & Morris et al. 2000 \\
\hline
\end{tabular}

\section{MATERIALS AND METHODS}

All of the tissues used were archival material obtained either from the authors' personal collections or where otherwise acknowledged. The tissues used had been fixed either in $10 \%$ neutral buffered formalin or Bouin's fixative prior to paraffin embedding according to standard protocols. Sections from the blocks were cut at approximately $5 \mu \mathrm{m}$, and floated onto glass slides for immunohistochemical staining with mAb B4.

Immunohistochemistry was conducted following the method of Adams and de Mateo (1994) with modifications regarding the chromagen and counterstain used. Briefly, de-paraffinized sections were ringed with a PAP pen and treated with $10 \%$ hydrogen peroxide in methanol, for $10 \mathrm{~min}$. After rinsing in Tris-buffered saline (TBS: $0 \cdot 05 \mathrm{M}$ Tris, $0 \cdot 15 \mathrm{M}$ $\mathrm{NaCl}, \mathrm{pH} 7 \cdot 6$ ) they were incubated with normal goat serum diluted 1:10(v/v) in TBS for $10 \mathrm{~min}$. The slides were tapped dry and the sections were incubated for $1 \mathrm{~h}$ in a moist chamber with undiluted $\mathrm{mAb} \mathrm{B} 4$ hybridoma supernatant at room temperature. The sections were rinsed again with TBS and incubated with goat anti-mouse $\mathrm{IgG}$ conjugated to horseradish peroxidase (Diagnostics Scotland, Carluke, UK) diluted 1:50 (v/v) in TBS for $30 \mathrm{~min}$ at room temperature. The sections were again rinsed in TBS before addition of the chromogen. For photomicrography, vector VIP (Vector Labs,
Burlingham, CA, USA) was used as the chromogen and methyl green as the counter-stain to enhance contrast, whereas for histological examination the chromogen $3^{\prime} 3^{\prime}$ diaminobenzidine and haemotoxylin were used to enhance tissue morphology. Sections of the embedded tissues were also included to use as controls for antibody binding while an additional section from each tissue block was histochemically stained with Giemsa. The control sections were tested using the above immunohistochemical protocol; however, the Mab B4 supernatant was replaced with Dulbecco's Modified Essential Medium. A positive control of rainbow trout kidney tissue infected with clinical T. bryosalmonae was also included with each batch of slides processed. All sections were examined for staining and photomicrographs obtained using an MRCgrab Zeiss imaging system.

Due to the characteristics of the immunostaining observed on some species, scanning electron microscopy of spores of Myxobolus macrocapsularis was also conducted. Fresh spores, isolated from a dissected roach Rutilus rutilus, were fixed in $2.5 \%$ glutaraldehdye in sodium cacodylate buffer, $\mathrm{pH} 7 \cdot 4$, for $24 \mathrm{~h}$. They were filtered through a $0 \cdot 1 \mu \mathrm{m}$ ceramic filter before post-fixing in $1 \%$ osmium tetroxide in sodium cacodylate buffer, $\mathrm{pH} 7 \cdot 4$, for $1 \mathrm{~h}$. After dehydrating through an acetone series, the filters were critical-point dried and sputter coated with $4 \mathrm{~nm}$ of gold and examined in a JEOL $5200 \mathrm{SEM}$ at $25 \mathrm{Kv}$. 
RESULTS

The fish species from which the tissues were collected, organ examined, infecting myxosporean species and any immunostaining attributable to $\mathrm{mAb}$ B4 are listed in Table 2. The species that immunostained all belonged to the genera Myxobolus, Thelohanellus and Sphaerospora. No staining was noted in myxozoans belonging to the genera Enteromyxum, Henneguya, Hoferellus, Kudoa, Myxidium or Myxobilatus. No discernable pattern attributable to the host environment was noted as samples from marine and freshwater hosts were examined with variable results.

It was noted that a few pseudoplasmodia within a kidney sample containing Chloromyxum truttae also immunostained. As this occurred on a minority of pseudoplasmodia that did not contain recognizable spores and the $C$. truttae sample obtained from Scotland did not immunostain, we consider that this immunostaining was attributable to a co-infection with an unidentified myxozoan.

Although, characteristics of the immunostaining varied, the plasmodial endoplasm and the outer surface of the spore valves immunostained for all of the species examined which reacted with the antibody (Table 3). Typical staining associated with plasmodia is presented in Fig. 1A. For the majority of species immunostaining of the valve surface occurred over the entirety of the spore, however, notable exceptions to this were Myxobolus artus, Thelohanellus pyriformis and a Myxobolus sp. present in the cartilage of the sand goby Pomatoschisus minutus in which staining did not occur at the apex of the spore. Generative cells, pansporoblasts and the contents of spores (cytoplasm and sporoplasm) rarely stained. Notable variations between species occurred with the presence or not of the antigen in the plasmodial ectoplasm and release of the antigen into associated areas of host tissue. Localization of the antigen in host tissue was often associated with areas of necrosis (Fig. 1B). Sections through immature plasmodia suggested that expression of the antigen was associated with sporogenesis with faint staining occurring on plasmodia containing generative cells but no obvious spores or pansporoblasts in contrast to more mature plasmodia undergoing sporogony that strongly stained. In addition, when present, the mucus envelopes of spores freed from ruptured plasmodia (i.e. spores of $M$. impressus, M. macrocapsularis, $M$. basilamellaris, $M$. intimus and $T$. pyriformis) were intensely immunostained (Fig. 1C). The immunostaining of envelopes was only observable on spores that were associated with the tissue when collected, such as those trapped between the gill lamellae, rather than within the tissues themselves.

No obvious non-specific cross-reaction of the antibody with host tissues was observed and the control sections did not immunostain. During the course of the study, co-infections with Trichodina, Ichthyophthirius and various digeneans were noted in some of the tissues examined. None of these co-infections were observed to cross-react with the antibody. In addition, occasional spores of Myxobolus spp. were observed in the vasculature of the gill arches of several fish species. There appeared to be no host reaction to these spores and while immunostaining was observed on their surface they could not be adequately speciated.

The results of the immunostaining are summarized in Table 3. Descriptions of specific species to highlight immunostaining characteristics are grouped into organ specificity as follows.

\section{Brain}

All of the myxosporean species tested that infected central nervous tissues reacted with mAb B4.

Spores of Thelohanellus oculileucisci were primarily located in loose groups of 5 to $>50$ under the meninges of both the optic tectum and cerebellum. Spore masses were also present within the valvula plica, tegmentum and stratum marginale of the optic tectum with occasional spores noted in the white matter and within the meninges. Immunostaining of the $\mathrm{B} 4$ antigen entirely covered the spore valves and was present in the tissues surrounding the spores. This staining appeared to be localized on nerves extending from the spore masses into the brain. Extensive staining was noted throughout the meninges, resulting in nearly the entire surface of the brain appearing covered with the antigen (Fig. 1D).

Individual spores of $T$. pyriformis were present throughout the meningial tissue though no plasmodial stages were observed. Immunostaining demonstrated the presence of the B4 antigen associated with the valves of the spore and in the host tissue immediately surrounding the spore. Immunostaining of the valves did not extend to the apex of spores, where the polar filament would be extruded. A few T. pyriformis spores associated with the section demonstrated mucus envelopes that immunostained towards the posterior of the spores.

The pathology associated with $M$. cotti was as previously described (Lom et al. 1989). Plasmodia, containing numerous mature spores, were present throughout the brain tissue. Masses of spores were also noted in the blood vessels of the meninges. Immunostaining of the B4 antigen on the parasite was primarily located on the remnants of the plasmodial cytoplasm, plasmodial envelope and on the valves of the spores. It was, however, occasionally noted that some mature spores did not stain with the antibody. Within the brain tissue there was extensive immunostaining radiating from the plasmodia extending nearly throughout the entire organ including the meninges. The immunostaining appeared 
Table 2. Myxozoan species examined from archive material for immunostaining with mAb B4

\begin{tabular}{|c|c|c|c|}
\hline Species & Organ & Host species & Reaction \\
\hline Chloromyxum lenorae & Kidney & Lota lota & - \\
\hline Chloromyxum reticulatum & Liver & Lota lota & - \\
\hline \multirow[t]{2}{*}{ Chloromyxum truttae } & Kidney & Salmo trutta (Wales, UK) & $+(?)$ \\
\hline & & Salmo trutta (Scotland, UK) & - \\
\hline \multirow{3}{*}{ Enteromyxum leei } & Intestine & Dicentrarchus labrax & - \\
\hline & & Scophthalmus maximus & - \\
\hline & & Sparus aurata & - \\
\hline Henneguya psorospermica & Gill & Perca fluviatilis & - \\
\hline Henneguy a creplini & Gill & Stizostedion lucioperca & - \\
\hline Henneguya sp. & Gill & Zingel zingel & - \\
\hline Hofferellus carassii $(K E D)$ & Kidney & Carassius auratus & - \\
\hline Kudoa sp. & Muscle & Pomatoschisus minutus & - \\
\hline \multirow{2}{*}{ Myxidium pfeifferi } & Bile duct, gall bladder & Rutilus rutilus & - \\
\hline & & Leuciscus leuciscus & - \\
\hline \multirow{5}{*}{ Myxidium rhodei } & Kidney & Rutilus rutilus & - \\
\hline & & Leuciscus cephalus & - \\
\hline & & Abramis brama & - \\
\hline & & Leuciscus leuciscus & - \\
\hline & & Phoxinus phoxinus & - \\
\hline Myxidium spinosum & Kidney & Aristichthys nobilis & - \\
\hline Myxobilatus gasterostei & Kidney & Gasterosteus aculeatus & - \\
\hline Myxobilatus legeri & Kidney & Leuciscus leuciscus & - \\
\hline Myxobilatus nostalgicus & Kidney & Tinca tinca & - \\
\hline Myxobolus acanthopagri & Intestine & Acanthopagrus australis & - \\
\hline Myxobolus alburni & Fin & Alburnus alburnus & + \\
\hline Myxobolus artus & Muscle & Cyprinus carpio & + \\
\hline Myxobolus basilamellaris & Gill & Cyprinus carpio & + \\
\hline Myxobolus bramae & Gill & Abramis brama & + \\
\hline Myxobolus conei & Liver & Pseudocaranx dentex & - \\
\hline Myxobolus cotti & Brain & Cottus gobio & + \\
\hline \multirow[t]{2}{*}{ Myxobolus cycloidas } & Intestine & Leuciscus cephalus & + \\
\hline & Parenchyma & Rutilus rutilus & + \\
\hline Myxobolus pseudodispar & Muscle & Rutilus rutilus & + \\
\hline Myxobolus cyprinicola & Intestine & Cургinus carpio & + \\
\hline \multirow[t]{2}{*}{ Myxobolus dispar } & Gill & Cyprinus carpio & + \\
\hline & Fin & & + \\
\hline Myxobolus drjagini & Gill & Hypophthalmichthys molitrix & + \\
\hline Myxobolus dujardini & Gill & Leuciscus cephalus & + \\
\hline Myxobolus farionis & Brain & Salmo trutta & + \\
\hline Myxobolus ibericus & Kidney & Salmo trutta & + \\
\hline Myxobolus impressus & Gill & Abramis brama & + \\
\hline Myxobolus intimus & Gill & Rutilus rutilus & + \\
\hline Myxobolus intrachrondrealis & Gill & Cурrinus carpio & + \\
\hline Myxobolus lentisuturalis & Muscle & Carassius gibelio & - \\
\hline Myxobolus longisporus & Gill & Cyprinus carpio & + \\
\hline \multirow[t]{2}{*}{ Myxobolus macrocapsularis } & Gill & Leuciscus cephalus & + \\
\hline & & Rutilus rutilus & + \\
\hline Myxobolus margitae & Gill & Alburnus alburnus & + \\
\hline Myxobolus muelleriformis & Gill & Lota lota & + \\
\hline Myxobolus obesus & Gill & Alburnus alburnus & + \\
\hline Myxobolus pavlovskii & Gill & Hypophthalmichthys molitrix & + \\
\hline Myxobolus pfeifferi & Muscle & Rutilus rutilus & - \\
\hline Myxobolus rotundus & Gill & Abramis brama & + \\
\hline Myxobolus sandrae & Muscle & Stizostedion lucioperca & - \\
\hline Myxobolus sp. & Gill & Barbus barbus & + \\
\hline Myxobolus sp. & Cartilage & Pomatoschisus minutus & + \\
\hline Myxobolus squamaphilus & Scale & Abramis brama & + \\
\hline Myxobolus thymalli & Muscle & Thymallus thymallus & + \\
\hline Myxobolus wellerae & Muscle & Notropis cornutus & + \\
\hline Sphaerospora cristata & Kidney & Salmo trutta & - \\
\hline Sphaerospora galinae & Kidney & Tinca tinca & + \\
\hline \multirow[t]{2}{*}{ Sphaerospora molnari } & Gill & Carassius auratus & - \\
\hline & & Cyprinus carpio & - \\
\hline \multirow[t]{3}{*}{ Sphaerospora renicola } & Kidney & Cyprinus carpio & + \\
\hline & Eye & & - \\
\hline & Swimbladder & & - \\
\hline Thelohanellus oculileucisci & Brain & Gobio gobio & + \\
\hline Thelohanellus nikolskii & Gill & Cyprinus carpio & + \\
\hline Thelohanellus pyriformis & Brain & Cyprinus carpio & + \\
\hline
\end{tabular}


Table 3. Summary of immunostaining of myxozoan parasites with mAb B4

(+ = staining with $\mathrm{mAb},-=$ no staining, $\mathrm{n} / \mathrm{s}=$ structure(s) not observed in section, $+/-=$ intermittent staining. * indicates immunostaining of mucus envelope on free spores.)

\begin{tabular}{|c|c|c|c|c|c|c|}
\hline \multirow[b]{2}{*}{ Species } & \multirow[b]{2}{*}{ Tissue } & \multicolumn{3}{|c|}{ Plasmodial constituents } & \multirow[b]{2}{*}{$\begin{array}{l}\text { Spore } \\
\text { surface }\end{array}$} & \multirow[b]{2}{*}{$\begin{array}{l}\text { Surrounding } \\
\text { host tissue }\end{array}$} \\
\hline & & Ectoplasm & Endoplasm & $\begin{array}{l}\text { Generative } \\
\text { cells }\end{array}$ & & \\
\hline Myxobolus cotti & Brain & $\mathrm{n} / \mathrm{s}$ & + & - & + & + \\
\hline Myxobolus drjagini & Brain & $\mathrm{n} / \mathrm{s}$ & + & - & + & + \\
\hline Myxobolus farionis & Brain & + & + & - & + & + \\
\hline Thelohanellus oculileucisci & Brain & $\mathrm{n} / \mathrm{s}$ & $\mathrm{n} / \mathrm{s}$ & $\mathrm{n} / \mathrm{s}$ & + & + \\
\hline Thelohanellus pyriformis & Brain & $\mathrm{n} / \mathrm{s}$ & $\mathrm{n} / \mathrm{s}$ & - & $+*$ & $+/-$ \\
\hline Myxobolus sp. & Cartilage & $\mathrm{n} / \mathrm{s}$ & $\mathrm{n} / \mathrm{s}$ & $\mathrm{n} / \mathrm{s}$ & + & - \\
\hline Myxobolus alburni & Fin & $+/-$ & + & - & + & + \\
\hline Thelohanellus nikolskii & Fin & $+/-$ & + & - & + & - \\
\hline Myxobolus basilamellaris & Gill & + & + & + & $+*$ & - \\
\hline Myxobolus bramae & Gill & + & + & - & + & - \\
\hline Myxobolus dispar & Gill & - & + & - & + & - \\
\hline Myxobolus dujardini & Gill & - & + & - & + & - \\
\hline Myxobolus impressus & Gill & $+/-$ & + & - & $+*$ & - \\
\hline Myxobolus intimus & Gill & $+/-$ & + & - & $+*$ & + \\
\hline Myxobolus intrachrondrealis & Gill & + & + & - & + & - \\
\hline Myxobolus longisporus & Gill & - & + & - & + & + \\
\hline Myxobolus macrocapsularis & Gill & + & + & - & $+*$ & - \\
\hline Myxobolus margitae & Gill & + & + & - & + & + \\
\hline Myxobolus muelleriformis & Gill & + & + & + & + & + \\
\hline Myxobolus obesus & Gill & + & + & - & + & - \\
\hline Myxobolus pavlovskii & Gill & - & + & - & + & - \\
\hline Myxobolus rotundus & Gill & + & + & - & + & - \\
\hline Myxobolus sp. & Gill & - & + & $\mathrm{n} / \mathrm{s}$ & + & - \\
\hline Myxobolus cycloidas & Intestine & $+/-$ & + & - & + & + \\
\hline Myxobolus cyprinicola & Intestine & - & + & - & + & - \\
\hline Myxobolus ibericus & Kidney & $\mathrm{n} / \mathrm{s}$ & $\mathrm{n} / \mathrm{s}$ & $\mathrm{n} / \mathrm{s}$ & + & - \\
\hline Sphaerospora galinae & Kidney & $\mathrm{n} / \mathrm{s}$ & $\mathrm{n} / \mathrm{s}$ & + & + & - \\
\hline Sphaerospora renicola & Kidney & - & + & - & + & + \\
\hline Myxobolus artus & Muscle & - & + & - & + & + \\
\hline Myxobolus pseudodispar & Muscle & - & + & - & + & - \\
\hline Myxobolus wellerae & Muscle & + & + & - & + & + \\
\hline Myxobolus thymalli & Muscle & + & + & - & + & + \\
\hline Myxobolus squamaphilus & Skin & $\mathrm{n} / \mathrm{s}$ & + & - & + & + \\
\hline
\end{tabular}

particularly intense around plasmodia within areas of atrophy.

Single spores or groups of 10-50 spores of $M$. farionis were contained within thin envelopes or plasmodia present throughout the grey and white matter of the spinal cord and in the medulla oblongata. The immunostaining was located on the cytoplasm of the plasmodia including the plasmodial envelope and the spore valves. Immunostaining occurred in the host tissue associated with the spores and appeared to be along the perineurium and individual neurones. Atrophy of the nervous tissue around the plasmodia was observed and these areas appeared intensely immunostained.

\section{Kidney}

Of the myxosporean species examined that infected the kidney, only spores or intra-tubular pseudoplasmodia stained using the antibody. Both Sphaerospora renicola and $S$. galinae had unusual immunostaining associated with them when compared to other species.

Pseudoplasmodia of $S$. renicola were observed at different stages of development within the tubular lumina including some that contained mature spores. In the maturing pseudoplasmodia, the cytoplasm immunostained but the developing spores contained within did not, while mature spores stained intensely around their periphery. Cytoplasmic threads emanating from the pseudoplasmodia also stained, as did the luminal surface of tubules harbouring the parasites. In some tubules, the staining extended through the tubule cells and onto the basement membrane. When this occurred, necrotic changes were noted within the tubule in association with the localized antibody. The changes included the cells becoming detached from one another, and necrosis of individual cells (Fig. 1B). Immunostaining of $S$. renicola did not occur for those extrasporogonic stages present within infected swimbladder or the retina. 


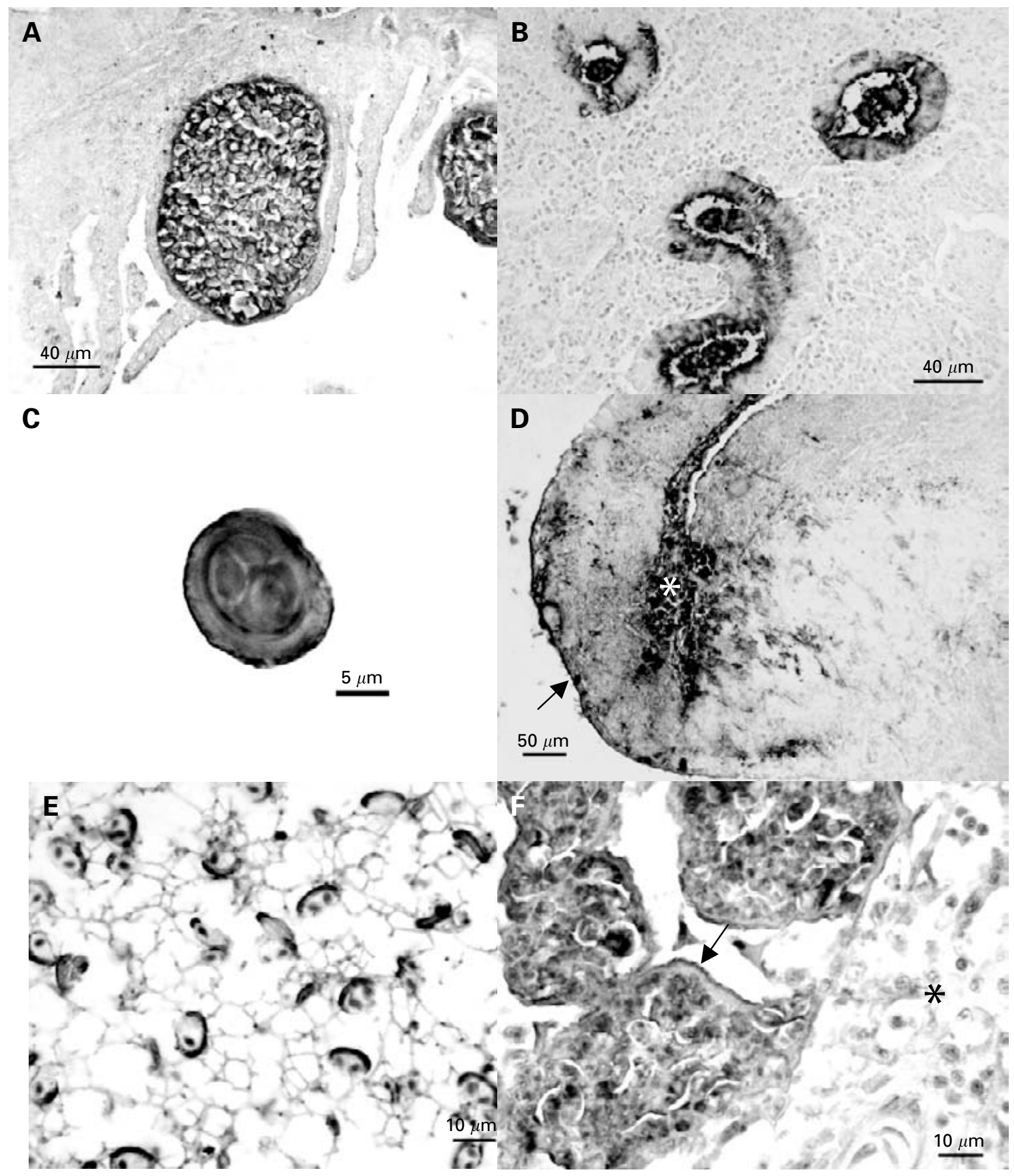

Fig. 1. (A-F). All figures are immunostained with mAb B4 using Vector Purple and counterstained with methyl green. (A) Plasmodia of Myxobolus mulleriformis in the secondary gill filament of Lota lota. (B) Pseudoplasmodia of Sphaerospora renicola in kidney tubules of Cyprinus carpio. Localization of antigen clearly shows diffusion through the tubule wall and localized areas of tubular necrosis. (C) Spore of Myxobolus intimus released from plasmodia and between gill filaments. Immunostaining demonstrates the retention of the mucus envelope around the spore. (D) Thelohanellus oculileucisci in brain of Gobio gobio. Intense immunostaining radiates from spore mass (*) into surrounding nervous tissue. Arrow indicates intense staining on meningies. (E) Spores within plasmodia of Myxobolus artus. Plasmodial endoplasm immunostains as a distinctive web-like structure while the spores are intensely immunostained towards their posterior pole. (F) Plasmodia of Myxobolus impressus demonstrating differential intensities of immunostaining. Arrow indicates intense staining on the surface of the plasmodium. Host tissue designated by *

Although pseudoplasmodia of $S$. galinae were observed within tubules, only maturing and mature spores were observed to stain using mAb B4. The immunostaining was located on the posterior surface of maturing spores within the pseudoplasmodia, and throughout mature spores with the most intense staining occurring on the surface of the valves. The mature spores did not have 
associated pseudoplasmodia. The tubule microvilli that were in direct contact with some mature spores also stained with the mAb. However, further diffusion of the immunostaining into host tissues was not observed.

\section{Muscle}

In addition to plasmodia, the $\mathrm{B} 4$ antigen was usually localized in the surrounding tissues of those myxozoans located within muscle. In particular it was associated with the perimysium, other connective tissues and around blood vessels. The immunostaining of the plasmodia and spores of Myxobolus artus was unique amongst all of the species examined.

Large plasmodia of $M$. artus, enclosed by connective tissue, were present between the skeletal muscle of the carp as previously described (Ogawa et al. 1992). Individual M. artus spores were also noted to occur freely between the muscle blocks of the fish although rupturing of plasmodia was not observed in the sections studied. Immunostaining occurred within the reduced endoplasm of the plasmodia, in surrounding muscle tissues and on individual spores both within the plasmodia and located individually throughout the host tissues. Within the plasmodia the spores were loosely packed and separated by an unusual web-like matrix of reduced immunostained endoplasm that was not observable using Giemsa staining. The spores were generally attached to this endoplasm by their posterior, the anterior end containing the polar filaments appearing not to be attached to any structures. The posterior of the mature spore valves that connected with the endoplasm was strongly stained (Fig. 1E). The immunostaining of the isolated spores observed free in between muscle blocks was similar to that observed in the plasmodia, being around the posterior of the spore valves. Immunostaining of host tissues included around the periphery of muscle fibres and extensive staining of the connective perimysium. Faint immunostaining was noted within the acellular bone surrounding the notocord and within the centre of the notocord, while intense staining was also noted within the central canal of the spinal cord and the ependymal cells lining this canal.

\section{Gill}

The majority of species examined were those that infected gill tissues. No species of Henneguya reacted with the antibody, even though plasmodia appeared superficially similar to the species of gill infecting Myxobolus examined which all immunostained. Diffusion of the B4 antigen was sometimes observed into the host tissues from the Myxobolus spp. plasmodia. For M. longisporus this immunostaining was evident on the plasmodial endoplasm and in adjacent host tissue but notably not on the intervening ectoplasmic layer.

For the majority of Myxobolus spp. only mature plasmodia containing spores were observed, however, for some species such as $M$. impressus a range of plasmodial development was noted. The plasmodia of this parasite were as described by Molnár and Székely (1999). Immunostaining on the immature plasmodia appeared granular over the entire cytoplasm. As the plasmodia developed, the immunostaining occurred on the endoplasm, and ectoplasm, with intense staining occurring on the surface of the latter (Fig. 1F). Immunostaining did not extend into the host tissue, but it was noted that debris caught between the gill filaments did stain. Included in this debris spores could be observed, that possessed intense staining on their mucus envelopes.

\section{Fin and scales}

The plasmodia of both Myxobolus alburni and $M$. squamaphilus immunostained with the antibody. However, in these species, small vesicles within the endoplasm of developing plasmodia were intensely stained around their periphery in comparison with the rest of the cytoplasm that was relatively lightly stained (Fig. 2A).

\section{Cartilage}

One Myxobolus sp. infecting cartilage, obtained from the archival material, had not been identified to species at the time of collection. For this parasite large numbers of oval spores, resembling $M$. artus present within chambers in the head cartilage of Pomatoschisus minutus but no plasmodia were present. Staining only occurred on the edge of spores and this resembled the staining associated with the spores of $M$. artus. No staining of cartilage was observed.

\section{Scanning electron microscopy of Myxobolus macrocapsularis}

The SEM analysis demonstrated the presence of the mucus envelope on the posterior of the ellipsoidal spores. The envelope was composed of numerous fibres that formed an anastomosing meshwork radiating from the spore (Fig. $2 \mathrm{~B}$ ).

\section{DISCUSSION}

The consistent immunostaining associated with the plasmodial endoplasm and the surface of the spore valves between myxosporean species indicates that $\mathrm{mAb} \mathrm{B} 4$ is binding to a relatively conserved antigen 


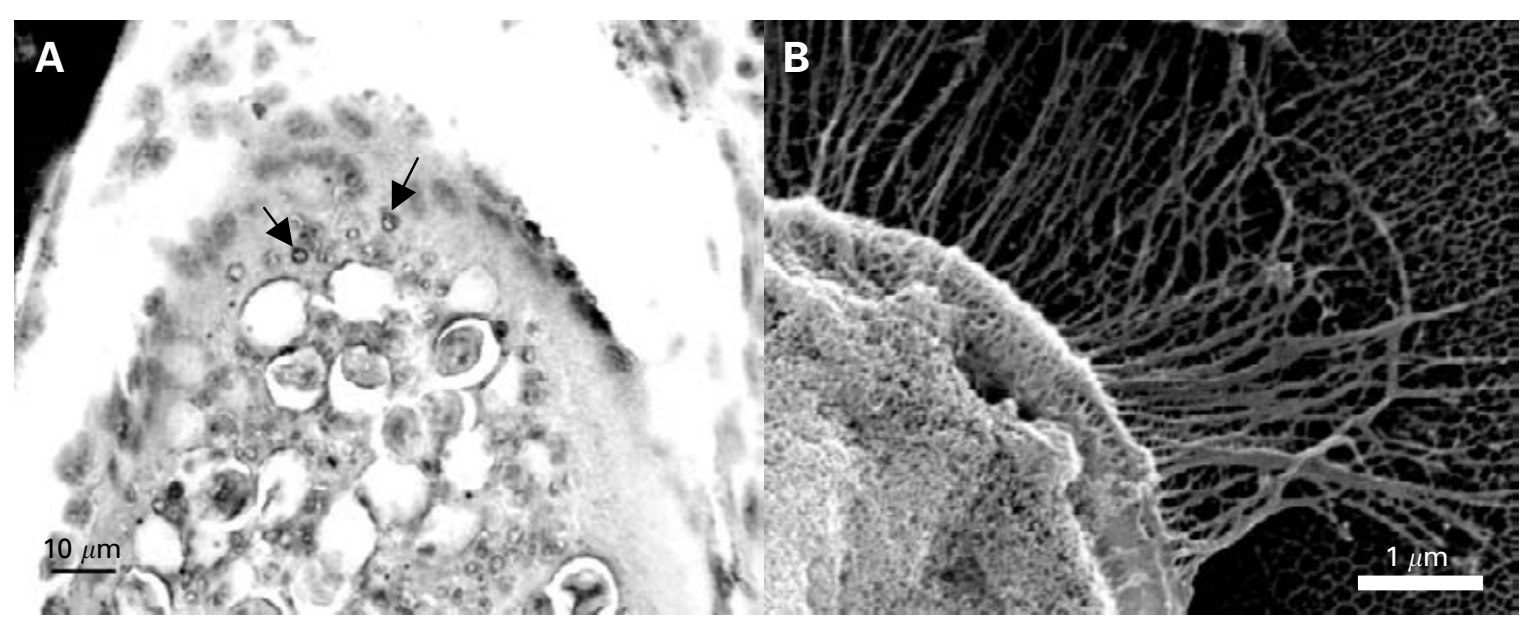

Fig. 2. (A) Plasmodia of Myxobolus alburni in fin of Alburnus alburnus immunostained with mAb B4. Arrows indicate intense immunostaining around small vesicles within endoplasm as compared to moderate staining of the endoplasm itself. (B) Scanning electron micrograph of Myxobolus macrocapsularis spore demonstrating fibrous web-like nature of mucus envelope.

that is expressed by different species of Myxozoa rather than different antigens possessing conformationally similar epitopes. The expression of this antigen does not correlate to the overall phylogeny of the phylum, so far being restricted to members of the genera Myxobolus, Thelohanellus, Sphaerospora and Tetracapsuloides. Additionally, it does not appear to correlate with host phylogeny or ecology or with the site of infection within the host.

The localization of the B4 antigen to the surface of spore valves in plasmodia and its presence within mucus envelopes of released spores demonstrates an intimate association with these structures. These envelopes are believed to aid spore buoyancy and dispersal and occur across a range of myxosporean genera, including Sphaerospora, Thelohanellus and Myxobolus and are described as being composed of mucus (Lom and Dyková, 1992). However, while little work has been conducted to verify the composition of these envelopes they do appear to be PAS negative, weakly metachromatically positive for Toluidine blue and can be digested by pepsin, suggestive of a proteinaceous composition (Lom and Vávra, 1963). The B4 antigen expressed by T. bryosalmonae is a protein (Morris et al. 1997) further confirming that at least one component of the envelope is proteinaceous. While the composition of the mucus envelopes has not been defined, it is notable that they display distinctive properties associated with hydrogels. These are gels, often composed of a 3-dimensional network of polymer chains, which entrap water molecules causing them to swell when hydrated (Trevors and Pollack, 2005). In particular, the envelopes rapid increase in size and maintenance of a defined shape when exposed to water together with size-dependent solute exclusion as demonstrated through the ability of Burri ink but not Indian ink to stain them (Lom and Vávra, 1963) demonstrate their affinities to a hydrogel. Members of the phylum Microsporidia are also recognized as possessing a mucocalyx surrounding the spores of some aquatic species that has analogous properties to the mucus observed around the myxozoan spores (Lom and Vávra, 1963; Vávra and Sprague, 1976). Scanning electron microscopy of this mucocalyx on Gurleya elegans demonstrated that it was composed of anastomising fibres that formed a web around the spore (Vávra and Barker, 1980) correlating to the polymer structure of a hydrogel. The SEM analysis of $M$. macrocapsularis in this study confirms that the envelope of myxosporean spores has a similar structure, verifying the physical nature of the surrounding material. The demonstration that this material can be fixed and processed for immunohistochemistry on free spores, albeit with a certain amount of shrinkage, also means that cytochemical studies to further determine the composition of the gel can be conducted.

Actinospores (myxosporean spores released from annelids) also contain a gel substance within their episporal cells that is capable of rapidly swelling in water (Lom and Vavrá, 1963). It is interesting to note that the B4 antigen has not been found in actinospores (Morris et al. 2004) suggesting differences between the gels observed on myxospores and within actinospores. If the structural gel polymers of the two spore types are homologous, this difference may be explained if the B4 antigen is entrapped within the matrix of the myxospore envelope rather than forming an integral part of the gel's polymers. This would also explain why the B4 antigen is capable of diffusing through tissues but does not appear to leach from the mucus envelope when spores are released from plasmodia.

Unlike other myxozoans, the spores of T. bryosalmonae are cytoplasmic, lacking proteinaceous 
valves, and do not appear to possess a mucus coating (Kent and Hedrick, 1986; Hedrick et al. 2004). As such, the association of the B4 antigen with $T$. bryosalmonae cannot be presently ascertained. However, it is possible that the valve cells contain a gel within them, causing them to expand when they are released from the fish.

For the majority of species examined the presence or absence of mucus envelopes have yet to be established using either SEM or the Indian ink method of Lom and Vávra (1963). Where an envelope has been identified on a species, the spores were immunostained with mAb B4. While Sphaerospora molnari, did not immunostain it has also been reported as possessing additional material attached to the surface of the spores, though this is considered to be of a different composition to the mucus envelopes usually associated with Myxozoans (Lom et al. 1983). In contrast, spores of Myxobolus longisporus immunostained but this species is reported as not possessing a mucus envelope (Dyková, Fiala and Nie, 2003). However, this was ascertained using Nomaski differential interference contrast microscopy to examine spores, which has yet to be compared to Indian ink in its effectiveness for detecting envelopes, especially those of a marginal thickness.

While the B4 antigen cannot be ascribed as occurring only on those myxozoan species that possess a hydrogel associated with their spores, it is consistently localized on the surface of myxosporean valve cells and, where present, the corresponding plasmodial cytoplasm. This suggests that the antigen is derived from this part of the plasmodia and deposited on the surface of the developing spore valve. This is exemplified by $M$. artus that clearly shows staining on the surface of the spores that are in direct contact with the endoplasm. Although this demonstrates that certain components associated with the valve surface and mucus envelope are derived from the plasmodia it is unclear whether the pericyte or valvogenic cells of pansporoblasts also contribute to its development.

For some of the myxozoan species examined, the B4 antigen is present both within the plasmodia and the surrounding tissues. Release of the B4 antigen into host tissue has also been identified for T. bryosalmonae and M.cerebralis (Morris et al. 1997, 2004). The reason for the release appears to be unclear although it may be associated with the breakdown of the plasmodia during the latter stages of sporogony. Tissues associated with the immunostaining of the B4 antigen often appeared to undergo atrophy or necrosis. Although this degeneration cannot be ascribed specifically to the presence of the B4 antigen it may represent necrotic events resultant from the release of additional plasmodial constituents. Such necrosis from plasmodial disintegration may be a relatively common phenomena allowing for the release of myxosporean spores from plasmodia either into the fishes circulatory system (Molnár and Kovács-Gayer, 1985; Longshaw, Frear and Feist, 2005 ) or, in the case of plasmodia located in the gill or skin, into the environment.

While the function and structure of the B4 antigen is presently unknown it may have an extracellular function related to the spore, once it is released from the plasmodia. Such functions could include proteolysis, explaining the tissue necrosis observed around individual Myxobolus spores in gill, that assists their release from the host (Molnár and Kovács-Gayer, 1985; Yokoyama et al. 1996). In addition it is interesting to note that hydrogel environments are conducive for enzymatic reactions (Wiggins, 1990) suggesting that any entrapped proteins, such as the $\mathrm{B} 4$ antigen, could remain functional in the extra piscine environment. Therefore, we conclude that the spores of many myxozoan species possess an antigen derived from the plasmodia that is deposited on their surface during maturation. This antigen is also present in the hydrogel envelopes of spores and suggests that such envelopes are likely to have additional roles in conjunction to being an aid to buoyancy.

The authors would like to thank the Department for Environment, Food and Rural Affairs for funding this research, Professor Hugh W. Ferguson for supplying samples of Hoferellus carassii and for interpretation of some of the histological specimens, Professor Iva Dyková for supplying a number of infected tissues used in the study and Edward Branson for supplying blocks of turbot tissue infected with Enteromyxum leei.

\section{REFERENCES}

Adams, A. and de Mateo, M. (1994).

Immunohisochemical detection of fish pathogens. In Techniques in Fish Immunology 3. (ed. Stolen, J. S., Fletcher, T. C., Rowley, A. F., Anderson, D. P., Kaattari, S. L., Zelikoff, J. T. and Smith, S. A.), pp. 133-145. SOS Publications, NJ, USA.

Dyková, I., Fiala, I. and Nie, P. (2003). New data on Myxobolus longisporus (Myxozoa: Myxobolidae) a gill infecting parasite of carp, Cyprinus carpio haematopterus, from Chinese lakes. Folia Parasitologica 50, 263-268.

Hedrick, R. P., Baxa, D. V., de Kinkelin, P. and Okamura, B. (2004). Malacosporean-like spores in urine of rainbow trout react with antibody and DNA probes to Tetracapsuloides bryosalmonae. Parasitology Research 92, 81-88. DOI : 10.1007/s00436-003-0986-3.

Kent, M. L., Andree, K. B., Bartholomew, J. L., E1-Matbouli, M., Desser, S. S., Devlin, R. H., Feist, S. W., Hedrick, R. P., Hoffmann, R. W., Khattra, J., Hallett, S. L., Lester, J. G., Longshaw, M., Palenzuela, O., Siddall, M. E. and Xiao, C. (2001). Recent advances in our knowledge of the Myxozoa. Fournal of Eukaryotic Microbiology 48, 395-413. DOI :10.1111/j.1550-7408.2001.tb00173.x

Kent, M. L. and Hedrick, R. P. (1986). Development of the PKX myxosporean in rainbow trout Salmo gairdneri. Diseases of Aquatic Organisms 1, 169-182. 
Lom, J. and Dyková, I. (1992). Protozoan parasites of fishes. In Developments in Aquaculture and Fisheries Science, vol. 26. Elsevier, Amsterdam, London, New York, Tokyo.

Lom, J., Dyková, I., Pavlásková, M. and Grupcheva, G. (1983). Sphaerospora molnari sp. nov. (Myxozoa: Myxosporea) an agent of gill skin and blood sphaerosporosis of common carp in Europe. Parasitology 86, 529-535.

Lom, J., Feist, S. W., Dyková, I. and Kepr, T. (1989). Brain myxoboliasis of bullhead, Cottus gobio L. due to Myxobolus jiroveci sp. nov. : light and electron microscope observations. Fournal of Fish Diseases 12, $15-27$.

Lom, J. and Vávra, J. (1963). Mucous envelopes of spores of the subphylum Cnidospora (Doflein 1901). Acta Societatis Zoologicae Bohemoslovenicae 27, 4-6.

Longshaw, M., Frear, P. A. and Feist, S. W. (2005). Descriptions, development and pathogenicity of myxozoan (Myxozoa: Myxosporea) parasites of juvenile cyprinids (Pisces: Cyprinidae). Fournal of Fish Diseases 28, 489-508. doi:10.1111/j.1365-2761.2005.00656.x

Marin de Mateo, M., McGeorge, J., Morris, D. and Kent, M. L. (1996). Comparative studies of PKX and Sphaerospora spp. from salmonids using lectin and monoclonal antibody staining techniques. Fournal of Fish Diseases 19, 55-63.

Molnár, K. and Kovács-Gayer, E. (1985). The pathogenicity and development within the host fish of Myxobolus cyprini Doflein 1898. Parasitology 90, 549-555.

Molnár, K. and Székely, C. (1999). Myxobolus infection of the gills of common bream (Abramis brama L.) in lake Balaton and in the Kis-Balaton reservoir, Hungary. Acta Veterinaria Hungarica 47, 419-432.

Morris, D. J., Adams, A. and Richards, R. H. (1997). Studies of the PKX parasite in rainbow trout via immunohistochemistry and immunogold electron microscopy. Fournal of Aquatic Animal Health $\mathbf{9}$, 265-273. DOI : $10.1577 / 1548-8667(1997)$ $009<0265$ :SOTPPI $>2.3 . \mathrm{CO} ; 2$
Morris, D. J., Adams, A., Feist, S. W., McGeorge, J. and Richards, R. H. (2000). Immunohistochemical and PCR studies of wild fish for Tetracapsula bryosalmonae (PKX), the causative organism of proliferative kidney disease. Fournal of Fish Diseases 23, 129-136. DOI:10.1046/j.1365-2761.2000.00227.x

Morris, D. J., El-Matbouli, M. and Adams, A. (2004). Extensive release of an antigen associated with the sporogonic stages of Myxobolus cerebralis (Myxozoa: Myxosporea) is detected by a heterologous antibody raised to Tetracapsuloides bryosalmonae (Myxozoa: Malacosporea). Folia Parasitologica 51, 215-220.

Ogawa, K., Delgahapitiya, K. P., Furuta, T. and Wakabayashi, H. (1992). Histological studies on the host response to Myxobolus artus Akhmerov 1960 (Myxozoa: Myxobolidae) infection in the skeletal muscle of carp, Cyprinus carpio L. Fournal of Fish Biology 41, 363-371.

Petchsupa, N. (2002). Studies on proliferative kidney disease with particular reference to vaccine development. Ph.D. thesis, University of Stirling, UK.

Trevors, J. T. and Pollack, G. H. (2005). Hypothesis: the origin of life in a hydrogel environment. Progress in Biophysics and Molecular Biology 89, 1-8. DOI:10.1016/j.pbiomolbio.2004.07.003

Vávra, J. and Barker, R. J. (1980). The microsporidian mucocalyx as seen in the scanning electron microscope. Folia Parasitologica 27, 19-21.

Vávra, J. and Sprague, V. (1976). Glossary for the Microsporidia. In Biology of the Microsporidia: Comparative Pathobiology, vol. 1. (ed. Bulla, L. A. and Chen, T. C.), pp. 341-363. Plenum Press, New York and London.

Wiggins, P. M. (1990). Role of water in some biological processes. Microbiological Reviews 54, 432-449.

Yokoyama, H., Tomonori, D., Ogawa, K., Arima, T. and Wakabayashi, H. (1996). Hemorrhagic anemia of carp associated with spore discharge of Myxobolus artus (Myxozoa: Myxosporea). Fish Pathology 31, 19-23. 